УДК 004.312.2:004.94

\author{
Р. П. Мельник, к.m.н., \\ О. Г. Мельник, к.т.н., с.н.с. \\ e-mail: indigo211212@gmail.com \\ Черкаський інститут пожежної безпеки імені Героїв Чорнобиля \\ Національного університету цивільного захисту України \\ вул. Онопрієнка, 8, м. Черкаси, 18034, Україна
}

\title{
РОЗРОБЛЕННЯ КОМП'ЮТЕРИЗОВАНОЇ СИСТЕМИ ПРОГНОЗУВАННЯ ПОЖЕЖ У ЖИТЛОВОМУ СЕКТОРІ
}

Дослідження присвячене розробленню структурної схеми комп'ютеризованої системи для реалізачії методу прогнозування передумов виникнення пожеж у житловому секторі. Розроблена комп'ютеризована система базується на використанні методу групового урахування аргументів за рахунок його адаптації до предметної області. Таблична реалізаиія методу забезпечить точне прогнозування пожеж у житловому секторі в реальному часі.

Встановлено, щчо найбільш ефективним методом підвищення швидкодії та достовірності роботи спеціалізованих засобів обчислювальної техніки є використання системи залишкових класів та інформаційної надлишковості. Подальші дослідження були спрямовані на пошук системи числення, яка найбільш ефективно реалізує систему залишкових класів з урахуванням сучасного розвитку обчислювальної техніки. Для забезпечення швидкості та достовірності реалізачії системи залишкових класів запропоновано реалізувати їі на основі позиџійної двійковочетвіркової системи числення з постійною кількістю одиниць.

Ключові слова: прогнозування пожеж, житловий сектор, комп'ютеризована система, система числення.

Вступ. Згідно зі статистичними даними World Life Expectancy [1] Україна належить до країн $з$ високим рівнем виникнення пожеж. Найбільша кількість пожеж, які створюють загрозу життю та здоров'ю людей, пошкоджують або знищують матеріальні цінності, виникає саме в житловому секторі. Порушення правил пожежної безпеки під час влаштування та експлуатації електроустановок є однією 3 основних причин виникнення пожеж (приблизно $15 \%$ від загальної кількості [2]). Причинами такої ситуації з пожежною безпекою в країні $\epsilon$ недосконала законодавча база щодо питань цивільної і техногенної безпеки, неналежне фінансування підтримки існуючих та впровадження нових сучасних систем протипожежного захисту.

Одним із шляхів запобігання виникненню пожеж у житловому секторі є реалізація профілактичних заходів на основі сучасних інформаційних технологій. Виконання цього завдання суттєво залежить від достовірності та оперативності інформації, що підлягає моніторингу, на основі якого приймаються управлінські рішення.

На сьогодні залишається невирішеною проблема автоматизації прогнозування передумов виникнення пожеж у житловому секторі.
Таким чином, нами ставилося важливе науково-технічне завдання - розроблення методів і засобів 3 метою реалізації задачі прогнозування передумов виникнення пожеж у житловому секторі в реальному часі.

Аналіз останніх досліджень. Науковий інтерес до вивчення питання щодо автоматизованого проектування, створення різних систем моніторингу та управління з кожним днем лише зростає. Так, у роботі [3] виконано дослідження щодо контролю та управління електроспоживанням. У дослідженні [4] здійснено випробування контролю споживання електроенергії в окремих точках електромережі. В роботі [5] запропоновано систему моніторингу електроспоживання в режимі реального часу. Але грунтовний аналіз цих досліджень показав, що вони не адаптовані до використання у сфері пожежної безпеки, оскільки не враховують параметри електромереж та їхні зміни, що можуть бути причинами виникнення пожеж.

У роботі [6] описано нове рішення для побудови систем моніторингу пожежної безпеки, що полягає у застосуванні бездротових датчиків та передаванні даних контрольованих параметрів пожежі в он-лайн режимі. Однак розглянуті системи фіксують безпосереднє виникнення пожеж, а не їхнє попередження. 
Можливість застосування апарату автоматизованих систем багаторівневого перетворення інформації для моніторингу пожежної безпеки та використання системи залишкових класів у випадку недостатньої інформативності розглянуто в роботі [7]. Продовженням вивчення питання щодо можливості використання системи залишкових класів з урахуванням розв'язання задачі прогнозування пожеж стала робота [8]. Але в дослідженнях [7, 8] не проведено аналіз і синтез кодованих систем числення, що адаптовані до реалізації системи залишкових класів.

Вивчення літературних джерел показало, що існуючі методи та засоби моніторингу пожеж не забезпечують виявлення саме передумов виникнення пожеж у житловому секторі. Все це дає можливість стверджувати, що доцільним є проведення дослідження щодо розроблення комп'ютеризованої системи прогнозування пожеж у житловому секторі на основі показників електромережі.

Метою роботи $\epsilon$ розроблення структурної схеми комп'ютеризованої системи для реалізації методу прогнозування передумов виникнення пожеж у житловому секторі.

Виклад основного матеріалу. В період активної інформатизації всіх сфер діяльності людини зростають вимоги й до ефективності прийняття та реалізації оперативних і стратегічних рішень на всіх рівнях управління Державної служби України з надзвичайних ситуацій. Ефективність прийняття рішень залежить від якості інформації, що обробляється, правильної іiі підготовки, аналізу, узагальнення та подання ії в належній формі.

Це свідчить про актуальність розроблення систем збору, передачі, опрацювання, візуалізації та документування статистичної інформації. В свою чергу, правильно підготовлену статистичну інформацію можна використовувати для оцінювання, моделювання та оперативного прогнозування виникнення пожеж у житловому секторі [9].

Найбільш ефективним підходом до удосконалення пожежної безпеки житлового сектора $є$ застосування технологій моніторингу 3 багаторівневим перетворенням інформації [10]. Ці технології дають змогу розв'язувати складні задачі отримання інтегральних показників стану об'єктів моніторингу пожежної безпеки як послідовність, в якій всі складові скоординовані між собою та адаптовані до зміни зовнішніх впливів.
У наукових роботах [11] доведено ефективність застосування методу групового урахування аргументів для прогнозування пожеж у житловому секторі та обрано показник, за допомогою якого можливо дистанційно виконати прогнозування споживання електроенергії. На основі даних для прогнозування передпожежного стану житлового сектора можна синтезувати адекватні прогнозні моделі за багаторядним алгоритмом методу групового урахування аргументів.

Модель прогнозування передумов виникнення пожежі в квартирі - це поліном Колмогорова-Габора, в якому використовуються лише операції додавання, віднімання, множення, піднесення до степеня, однак операцій ділення та порівняння немає. На кожну квартиру необхідно отримати таку модель, до того ж, отримані моделі 3 деяким часом стають застарілими та неактуальними, тому періодично потрібно їх перераховувати. Отримання даних із житлових приміщень потребує великих працезатрат, часу та наявності засобів обчислювальної техніки з високими технічними параметрами. Тому проведення постійного моніторингу стану електромережі житлових будинків $є$ майже неможливим. Це стало основою для проведення подальших досліджень.

За результатами проведених досліджень і огляду існуючих підсистем збору первинних даних для прогнозування аварійного стану електромереж нами було розроблено структурну схему комп'ютеризованої системи, що зображена на рис. 1. Схема демонструє реалізацію методу прогнозування передумов виникнення пожеж у житловому секторі.

Система моніторингу складається 3 таких підсистем: збору даних, попередньої обробки даних, прогнозування та передачі даних. Підсистема збору даних призначена для отримання даних щодо електроспоживання 3 житлового сектора (W). В підсистемі попередньої обробки даних розраховується споживання електроенергії за певні інтервали часу, а також диференційне оцінювання споживання електроенергії. Підсистема прогнозування виконує головну роль в оцінюванні стану житлового приміщення і забезпечує оцінювання вхідних даних на основі моделі реалізації. Підсистема передачі даних отримує результат прогнозування (R) 3 підсистеми прогнозування та передає його по каналах зв'язку (S). 


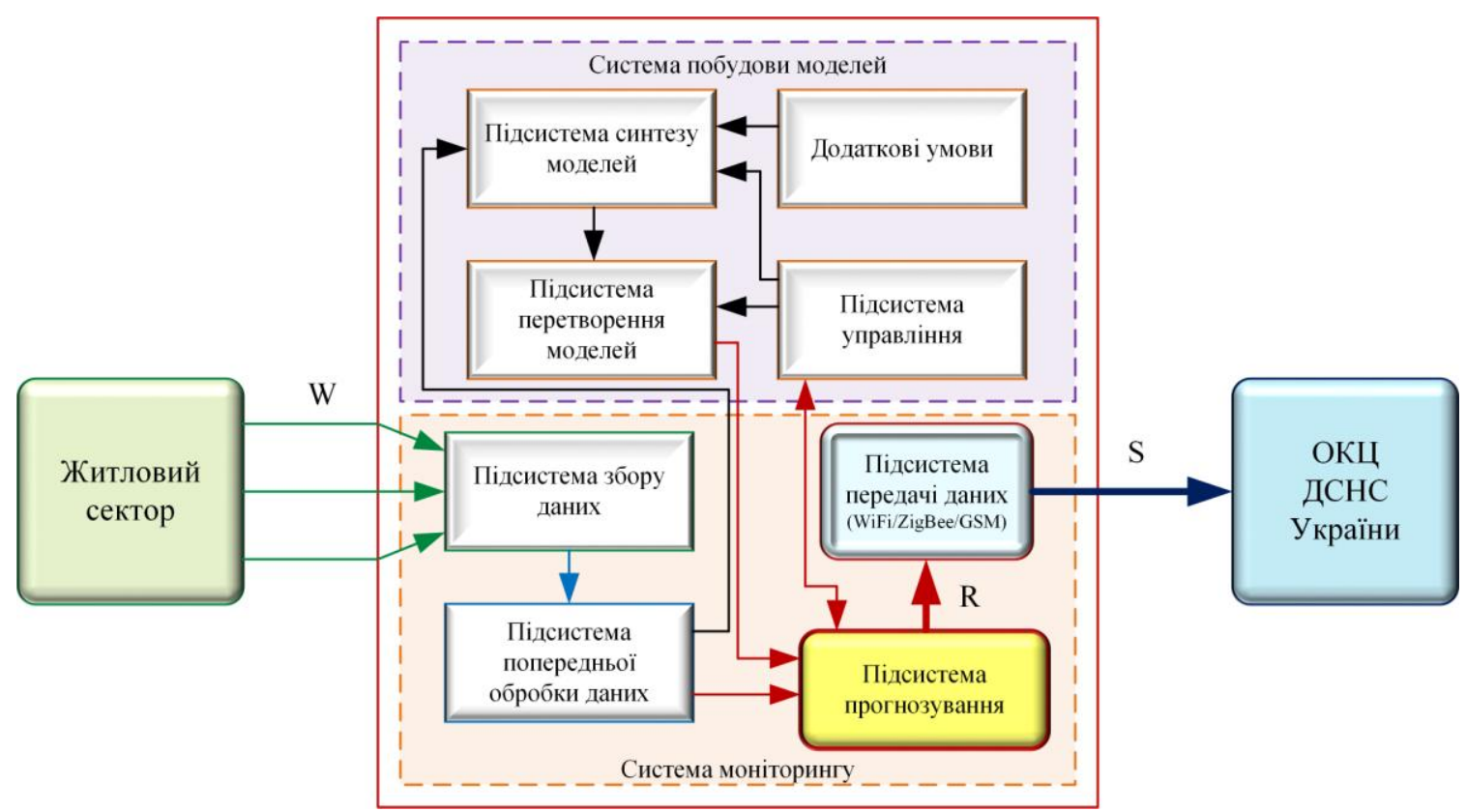

Рисунок 1 - Структурна схема комп'ютеризованої системи для реалізації методу прогнозування передумов виникнення пожеж у житловому секторі

До складу системи побудови моделей входять такі підсистеми: управління, синтезу моделей і перетворення моделей. Підсистема управління призначена для прийняття рішення на перебудову моделі за результатами прогнозування. Підсистема синтезу моделей працює 3 попередньо обробленими даними споживання електроенергії за певні проміжки часу та створює на основі методу групового урахування аргументів моделі конкретних квартир. Підсистема перетворення моделей відповідно перетворює синтезовані моделі в моделі, що допустимі для використання програмно-апаратними засобами підсистеми прогнозування.

Підсистема перетворення моделей реалізується на апаратному рівні, а підсистеми збору даних, попередньої обробки даних, прогнозування, управління та синтезу моделей - на програмному рівні.

У наукових роботах $[7,8]$ підтверджено можливість застосування системи залишкових класів для забезпечення швидкості розрахунку моделей квартир, обгрунтовано правильність вибору системи числення, яка найбільш ефективно виконує операції додавання, віднімання та множення. В зазначеній системі числення всі числа є своїми залишками від ділення на обрану систему основ. У результаті розрахунків поліномів кожної окремої квартири модель буде наведено у табличній формі.

(C) Р. П. Мельник, О. Г. Мельник, 2019

DOI: $10.24025 / 2306-4412.1 .2019 .164756$
Подальші дослідження були спрямовані на пошук системи числення для реалізації системи залишкових класів. Придатність для практичного використання системи числення визначається низкою факторів [12]: можливістю подання будь-якого числа в заданому діапазоні; однозначністю подання; простотою і стислістю запису чисел; легкістю оволодіння системою. Нами було досліджено можливості застосування двійково-шестіркової та двійково-четвіркової систем числення для обрання форми подання інформації. Основним недоліком двійково-шестіркової системи числення $\epsilon$ складність перекодування 3 двійкової безнадлишкової системи числення, і навпаки [13]. Тому нами було обрано позиційну двійковочетвіркову систему числення з постійною кількістю одиниць.

Перевагами обраної системи числення $\epsilon$ легке перетворення, гарантоване знаходження помилок та велика несиметрія нулів і одиниць, що дає можливість адаптуватися до реальних каналів зв'язку та обчислювальної техніки [12, 13]. У двійково-четвірковій системі числення 3 постійною кількістю одиниць система залишкових класів ефективно реалізується 3 урахуванням існуючої елементної бази комп'ютерної техніки, а також уможливлює гарантоване виявлення помилок прогнозування. На рис. 2 зображено результати проведеного дослідження щодо виявлення та пропускання помилок 
у двійково-четвірковій системі числення 3 постійною кількістю одиниць залежно від розрядності інформації.

Як свідчать результати розрахунку, така система числення гарантовано виявляє всі помилки непарної кратності при значній простоті пристрою контролю інформації. 3 цього ви- пливає, що двійково-четвіркову систему числення можна вважати перспективною для застосування в спеціалізованих обчислювальних системах прогнозування передумов виникнення пожеж у житловому секторі та системах управління пожежною безпекою.
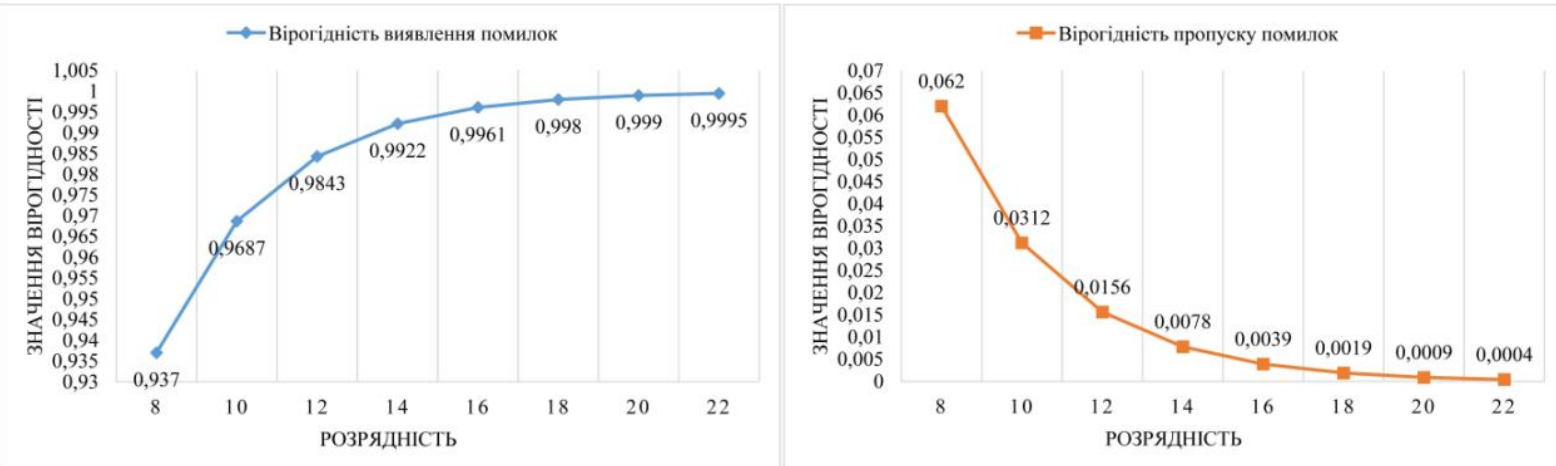

Рисунок 2 - Вірогідність виявлення і пропуску помилок у двійково-четвірковій системі числення з постійною кількістю одиниць залежно від розрядності інформації

Необхідно зазначити, що в цьому науковому дослідженні ми звертаємо особливу увагу саме на відсутність помилкового прогнозування. Помилки прогнозування передумов виникнення пожеж у житловому секторі можуть призвести до нераціонального використання сил і засобів органів і підрозділів Державної служби України 3 надзвичайних ситуацій та значної втрати коштів.

Висновок. Запропоновано структурну схему комп'ютеризованої системи для реалізації методу прогнозування передумов виникнення пожеж у житловому секторі. Розроблена комп'ютеризована система базується на використанні методу групового урахування аргументів за рахунок його адаптації до предметної області.

\section{Список літератури}

1. World health rankings. URL: http://www. worldlifeexpectancy.com/cause-of-death/fires/ by-country/ (дата звернення: 15.01.2019).

2. Аналіз масиву карток обліку пожеж (POG_STAT) за 12 місяців 2018 року. URL: http://undicz.dsns.gov.ua/ua/Analiz-masivukartok-obliku-pozhezh.html (дата звернення: 15.01.2019).

3. Jihyun Lee, Jiyeon Son, Jeu Young Kim, Jun Hee Park. Planning energy consumption of home appliances in real home network environments. 2012 IEEE International
Conference on Consumer Electronics (ICCE). Las Vegas, 2012. P. 524-525. doi: 10.1109/ICCE.2012. 6161802

4. Moayedi S., Shom S., Harms A., Alahmad M. Real time power monitoring detection based on sequence time domain reflectometry approach. Journal of Computer and Communications. 2018. No. 6. P. 92-103. doi: 10.4236/jcc.2018. 61010

5. Alahmad M., Nader W., Neal J. et al. Real time power monitoring \& integration with BIM. IECON 2010 - 36th annual conference on IEEE industrial electronics society. 2010, 7-10 Nov. P. 2454-2458. doi: 10.1109/ IECON.2010.5675385

6. Vidyashree P., Pushpalatha S. The design and implementation of building fire monitoring system using zigbee-wifi gateway. International Research Journal of Engineering and Technology (IRJET). 2017. Vol. 4. Iss. 7. P. 3030-3032.

7. Дендаренко В. Ю., Мельник О. Г., Чепурний Г. П. Побудова інформаційної системи моніторингу пожежної безпеки. 3бірник наукових працьь Харківського університету Повітряних Сил. 2014. Вип. 3 (40). C. 167-170.

8. Мельник О. Г. Формування вимог до векторної основи системи залишкових класів 3 урахуванням рішення задачі прогнозування пожеж у житловому секторі. Системи 
озброєння $і$ військова техніка. 2015. № 1 (41). C. 165-167.

9. Мельник О. Г., Мельник Р. П. Оцінка оперативності прогнозування пожеж у житловому секторі. Вісник Черкаського державного технологічного університету. Серія: Технічні науки. 2017. № 4. С. 27-31.

10.Голуб С. В. Багаторівневе моделювання в технологіях моніторингу оточуючого середовища: монографія. Черкаси: Вид-во ЧНУ ім. Б. Хмельницького, 2007. 220 с.

11.Мельник О. Г., Мельник Р. П. Застосування методу групового урахування аргументів до прогнозування пожеж у житловому секторі. Надзвичайні ситуаичї: безпека та захист: матеріали VII всеукр. наук.-практ. конф. 3 міжнар. участю. Черкаси, 2017. C. 7-8.

12.Пантєлєєва Н. М., Рудницький В. М. Теоретичні основи створення природнонадійних комп'ютерних систем: посібник. Черкаси: Брама-Україна, 2009. 200 с.

13. Рудницкий В. Н., Казаринова Н. Л., Н Нечипоренко О. В. Синтез арифметических устройств по условию надежности на основе систем счисления с постоянным числом единиц. Збірник наукових працьь IПМЕ НАНУ. 2005. Вип. 29. С. 3-11.

\section{References}

1. World health rankings. URL: http://www. worldlifeexpectancy.com/cause-of-death/fi res/by-country/

2. The analysis of the set of fire accounting cards (POG_STAT) for 12 months of 2018. URL: http://undicz.dsns.gov.ua/ua/Analiz-masivukartok-obliku-pozhezh.html

3. Jihyun Lee, Jiyeon Son, Jeu Young Kim, Jun Hee Park (2012). Planning energy consumption of home appliances in real home network environments. 2012 IEEE International Conference on Consumer Electronics (ICCE), Las Vegas, pp. 524-525. doi: 10.1109/ICCE.2012.6161802

4. Moayedi, S., Shom, S., Harms, A., Alahmad, M. (2018). Real time power monitoring detection based on sequence time domain reflectometry approach. Journal of Computer and Communications, No.6, pp. 92-103. doi: 10.4236/jcc.2018. 61010
5. Alahmad, M., Nader, W., Neal, J. et al. (2010). Real time power monitoring \& integration with BIM. IECON 2010 - 36th annual conference on IEEE industrial electronics society, 7-10 Nov., pp. 24542458. doi: 10.1109/IECON.2010.5675385

6. Vidyashree, P., Pushpalatha, S. (2017). The design and implementation of building fire monitoring system using zigbee-wifi gateway. International Research Journal of Engineering and Technology (IRJET), vol. 4, iss. 7, pp. 3030-3032.

7. Dendarenko, V. Yu., Melnyk, O. G., Chepurnyi, G. P. (2014). Construction of information system for fire safety monitoring. Zbirnyk naukovykh prats Kharkivskoho universytetu Povitrianykh Syl, iss. 3 (40), pp. 167-170 [in Ukrainian].

8. Melnyk, O. G. (2015). Formation of requirements to vector foundation of residual classes system taking into account the solution of the problem of fire forecasting in housing sector. Systemy ozbroyennya $i$ vijskova tehnika, No. 1 (41), pp. 165-167 [in Ukrainian].

9. Melnyk, O. G., Melnyk, R. P. (2017). Evaluation of fire forecasting efficiency in housing sector. Visnyk Cherkaskogo derzhavnogo technolohichnogo univer-sytetu. Seria: Tehnichni nauky, No. 4, pp. 27-31 [in Ukrainian].

10.Golub, S. V. (2007). Multilevel modeling in the technologies of environment monitoring: monograph. Cherkasy: Vyd-vo ChNU im. B. Khmelnytskoho, 220 p. [in Ukrainian].

11.Melnyk, O. G., Melnyk, R. P. (2017). The use of group argument accounting method to fire forecasting in housing sector. Nadzvychaini sytuatsii: bezpeka ta zakhyst: materials of the VII All-Ukr. sci.-pract. conf. with internat. participation. Cherkasy, pp. 7-8 [in Ukrainian].

12.Pantjeljejeva, N. M., Rudnyckyj, V. M. (2009). Theoretical foundations for the creation of natural reliable computer systems. Cherkasy: Brama-Ukraina, 200 p. [in Ukrainian].

13.Rudnickij, V. N., Kazarinova, N. L., Nechiporenko, O. V. (2005). The synthesis of arithmetic units by relience condition based on notation systems with fixed bit count. Zbirnyk naukovych prac IPME NANU, iss. 29, pp. 3-11 [in Russian]. 
R. P. Melnyk, Ph.D.,

O. G. Melnyk, Ph.D., senior researcher

e-mail: indigo211212@gmail.com

Cherkasy Institute of Fire Safety named after Chornobyl Heroes

of National University of Civil Defense of Ukraine

Onoprienko str., 8, Cherkasy, 18034, Ukraine

\section{DEVELOPMENT OF A COMPUTERIZED FIRE FORECASTING SYSTEM IN RESIDENTIAL SECTOR}

The research is devoted to the development of a structural scheme of the computerized system for the implementation of the method for predicting the preconditions of fire emergence in residential sector. The developed computerized system is based on the use of the method of group consideration of arguments due to its adaptation to the subject area. Table implementation of the method will provide accurate fire forecasting in residential sector in real time.

It is established that the use of the system of residual classes and information redundancy is the most effective method for increasing the speed and reliability of the work of specialized computing means. Further research was aimed at finding a numerical system that most effectively implements the system of residual classes, taking into account the current development of computer technology. To ensure the speed and reliability of the implementation of the system of residual classes, it is proposed to implement it based of a positional biquatemary system with a constant number of units.

In a biquatemary system with a constant number of units, the system of residual classes is effectively implemented taking into account the existing elemental base of computer technology. As the results of the calculations show, such a system of calculations is guaranteed to detect all errors of odd multiplicity with a significant simplicity of information control. It follows that a binary quadruple system can be considered promising for the use in specialized computer systems to predict the preconditions for the emergence of fires in the residential sector and fire safety management systems.

In this research we have paid special attention to the lack of false prediction. Mistakes in forecasting the preconditions for the emergence of fires in the residential sector may lead to inefficient use of forces and means of bodies and units of the State Emergency Service of Ukraine and significant loss of funds.

Keywords: fire forecasting, residential sector, computerized system, numerical system. 